TECHNICAL PAPER

\title{
METHOD TO EVALUATE THE EFFICIENCY OF MANUAL OVERHEAD IRRIGATION IN CITRUS ROOTS TOCK LINER PRODUCTION ${ }^{1}$
}

Doi:http://dx.doi.org/10.1590/1809-4430-Eng.Agric.v36n4p 724-735/2016

\section{CONAN A. SALVADOR ${ }^{2 *}$, RHUANITO S. FERRAREZI ${ }^{3}$, CARLOS V. G. BARRETO ${ }^{4}$, ROBERTO TESTEZLAF ${ }^{3}$}

\begin{abstract}
Brazil produces grafted citrus seedlings in closed screen houses to reduce pest and disease incidence. Irrigation is usually performed by hand using either breaker nozzles or drilled polyvinyl chloride (PVC) pipe wands on garden hoses. Rootstocks are produced in cone-shaped containers filled with soilless potting mix. Since the containers have a small upper diameter, nutrient solution capture is reduced with the potential to cause environmental contamination from inefficient fertigation. This study provides a method to assess the efficiency of manual overhead irrigation systems used in liner production. The method consists of determining both the volume of water applied and volume lost (i.e., directly and by percolation) in order to obtain an estimate of the percentage of water loss, irrigation efficiency, and the drainage fraction. The method was tested in a commercial facility under standard production practices. The method's attributes included simplicity, quick sampling and data collection, and accuracy. The evaluated nursery was found to have low irrigation efficiency (27.14\%) and excessive nutrient solution losses (72.86\%). Considering an average production of 300,000 liners per year on $20,000 \mathrm{~m}^{2}$, we determined an annual solution loss of $221.8 \mathrm{~m}^{3}$ with an average environmental release of $158.9 \mathrm{~kg}$ of fertilizer. Therefore, more efficient irrigation systems are necessary for sustainable citrus rootstock liners production.
\end{abstract}

KEYWORDS : citrus propagation, drainage fraction, irrigation efficiency, nursery production.

\section{INTRODUCTION}

High-quality seedlings are necessary for the establishment of healthy citrus groves. In São Paulo (Brazil), the state government regulates citrus seedlings production by strict regulations focused on producing pest and disease-free plants including mandatory cultivation in screen houses (CARVALHO et al., 2005). The system has become a global model due to the use of technologies that result in seedlings with high phytosanitary quality.

The citrus seedlings production system has three components: rootstock liners, rootstock seedlings, and grafted seedlings. The liners are cultivated in $50-\mathrm{cm}^{3}$ cone-shaped containers while the rootstock and grafted seedlings are cultivated in 4 to $7 \mathrm{~L}$ soft containers. All components use a soilless potting mix (ROZANE et al., 2009; TEIXEIRA et al., 2009a). According to SALVADOR (2010), rootstock liner production can be divided into four stages of development: 1) germination and plant establishment (GE), 2) early development (ED), 3) intermediate development (ID), and 4) final development (FD), with an average duration of 30 days per stage.

As rootstock liners are grown in small-volume containers, frequent irrigation and fertilization are required to meet crop water and nutrient demands (BUMGARNER et al., 2008; TEIXEIRA et al., 2010). Most nurseries irrigate using manual overhead systems using hoses attached to either breaker nozzles or PVC pipe wands. Few growers use expensive automated systems such as spray bars. Manual overhead systems are characterized by minimal control of solution delivery often

\footnotetext{
${ }^{1}$ Part of the master's thesis in Agricultural Engineering of the first author.

${ }^{2}$ Federal Rural University of Rio de Janeiro/Seropédica - RJ, Brazil.

${ }^{3}$ University of Campinas/Campinas - SP, Brazil.

${ }^{4}$ National Institute of Industrial Property/Rio de Janeiro - RJ, Brazil.

*Corresponding author. E-mail: conan@ufrrj.br

Received in: 7-30-2013

Accepted in: 7-9-2015
} 
leading to excessive or deficient irrigation, reduced irrigation efficiency, increased production costs, and environmental contamination (SOUZA et al., 2011a).

The irrigation design should ensure uniform water delivery and efficient distribution regardless of the system used (JUSTI et al., 2010). However, manual overhead irrigation has no water flow or uniformity control, resulting in uneven irrigation. Water and nutrient solution excess is directly disposed into the soil and may cause salinization, in addition to serious environmental impacts and increase of production costs (GIRARDI et al., 2010; SOUZA et al., 2011b; FERRAREZI et al., 2012). Adequate irrigation management and mitigation of any environmental impacts are necessary for sustainable plant production, especially because the current regulations do not specify recommendations for water and nutrient management.

Unfortunately, the specifics of rootstock production in screen houses (i.e., use of smallvolume containers and soilless potting mix), do not allow the use of existing irrigation assessment methods for sprinkler and drip irrigation. Therefore, a new method that allows for the determination of water use efficiency under these restricted conditions is required. This method will assist decision-makers in determining the most appropriate irrigation strategies for citrus seedlings production.

Water application efficiency depends on the irrigation system, operating capacity, and the adopted management strategy. According to ZINATI (2005), irrigation efficiency can be expressed using three parameters related to water application: 1) uniformity of application, 2) amount of water retained in the substrate after irrigation (application efficiency), and 3) the ratio between the amount of water entering the container and that leached in-between containers (interception efficiency). However, manual overhead irrigation typically distributes water irregularly due several factors including variable application rates, irrigator speed and effect on water flow rate, and variation caused by proximity to the plants and plant location within the bench. Therefore, the parameter 'uniformity of application' is not appropriate in these systems and a new method is required to determine the proper water management for seedlings production.

This study presents a method to evaluate the efficiency of manual overhead irrigation in citrus rootstock liners cultivated in screen houses.

\section{MATERIAL AND METHODS}

This study was divided into the following phases: 1) characterization of the major production components including the manual overhead irrigation operation, 2) development of a method for assessing the efficiency of manual overhead irrigation in citrus rootstock liner production, and 3) application of method under commercial conditions using rootstock liners grown in $50-\mathrm{cm}^{3}$ coneshaped containers.

\section{Characterization of the major production components including the manual overhead irrigation operation}

A technical visit was performed at a commercial certified citrus seedling nursery (Citrograf Mudas, Rio Claro, São Paulo, Brazil) to identify the major production components and the manual overhead irrigation system's characteristics. This company is part of the Citrus Nurserymen Association (Vivecitrus) and has been recognized by the industry for using cutting-edge technology in the production of high quality seedlings.

Based on this visit, we designed a method to evaluate the manual overhead irrigation system's efficiency. The method consisted of a survey ( $\mathrm{N}=56$ nurseries; data not shown) and one on-site nursery visit for irrigation performance evaluation. The survey data included site characterization, identification of water source, cultural practices (focused specifically on irrigation and management systems), nursery and nurseryman identification, nursery area, seedling production, irrigation system identification, irrigation management practices, and substrate and fertilizer source. More details about the survey are available in SALVADOR (2010). 
The on-site data collection procedure assessed each the four 30-day stages of development: GE, ED, ID and FD. This classification was useful to detect the "umbrella effect" (i.e., water redirection by leaves) and reduce data variability over time. A period of 120 days was adopted as the growing period for the citrus rootstock liners based on ROZANE et al. (2009) and TEIXEIRA et al. (2009b). This growing period allow the plants to reach an appropriate shoot height and stem diameter for transplanting into larger containers for grafting. However, one must note the existence of species, varietal and seasonal variability as reported by BATAGLIA et al. (2008).

\section{Development of a method for assessing the efficiency of manual overhead irrigation Determination of the irrigation system water flow rate and pressure}

The irrigation efficiency evaluation started with the determination of the water and nutrient solution volume applied by the manual overhead irrigation. The water was provided through a 3/4inch rubber hose. We decided to use a volumetric method due to its simplicity, repeatability, and accuracy. It consists of collecting a volume applied in a graduated container for a specific time period with three replications per sample. The flow rate was calculated by dividing the collected volume by the time interval.

The pressure was measured using a Bourdon gauge for low pressure (Model 3822 002; Genebre S.A., Barcelona, Spain) installed on the water inlet. The average pressure over the study period was $117.9 \mathrm{kPa}$. The pressure remained constant, ensuring the flow rate was constant during the water application interval. Both the pressure and water flow must remain constant while assessing irrigation efficiency.

\section{Determination of the mass balance components}

We used a $2 \times 10 \mathrm{~m}$ bench with approximately 21,300 citrus rootstock liners (49 plants per $0.046 \mathrm{~m}^{2}$ ) in $50-\mathrm{cm}^{3}$ cone-shaped containers.

The mass balance of the irrigation system was calculated as the sum of the water input, water retention, and water output such as in RIBEIRO et al. (2014). Irrigation and fertigation were considered the only water inputs. Water retention was divided into: water retained in the canopy (leaves and branches) - which can potentially evaporate; water available in the substrate, which is a function of the water content and water holding capacity; and water retained by the support structure and on the outer surface of the containers - which can also evaporate. Despite the fact these three components represent the total amount of water retained in the system, only the water available in the substrate was considered for the irrigation efficiency calculation. Moreover, the system water outputs were: water passing through the empty spaces between the containers; water leaching through the substrate (i.e., >water holding capacity); and water splashing or operator error. Regarding the water application losses, direct losses may be considered as the volume passing through a system and not being retained. Indirect losses represent the water not retained by the system or water not used for plant growth (i.e. lost by evaporation).

However, determining the mass balance considering all of the parameters that contribute to the indirect loss is not simple; it would be necessary to collect data for all of these components. Considering the fact that production of citrus rootstock liners is characterized by high irrigation frequency, and the need for quick decisions to adjust the water management, such measurements are not realistic for commercial nurserymen. Having to determine these parameters would be against the main goal of this method which should be characterized by simplicity, fast sampling and data collection, and accurate efficiency assessment to increase the adoption by nurserymen. Therefore, these components were not included in our proposed method.

We developed a procedure for quantifying the main water losses, by collecting the applied water or nutrient solution that passes directly through the spaces between the containers and the leachate. We selected a $3-\mathrm{m}^{2}$ plot per bench with uniform plant development. In each plot, three 0.04- $\mathrm{m}^{2}$ sub-sampling areas containing 49 containers each were randomly defined (Figure $1 \mathrm{a}$ ). A 24 $\times 5 \mathrm{~cm}$ plastic bag was placed underneath all the cone-shaped containers of each sub-sampling area in order to collect the solution leached through the container (Figure 1b). Additionally, an $18 \times 23$ 
$\mathrm{cm}$ styrofoam tray was installed underneath each sub-sampling area to collect the solution that passed through the empty spaces between the cone-shaped containers (Figure 1c). The supplies were disposed after each sampling to avoid potential disease contamination.

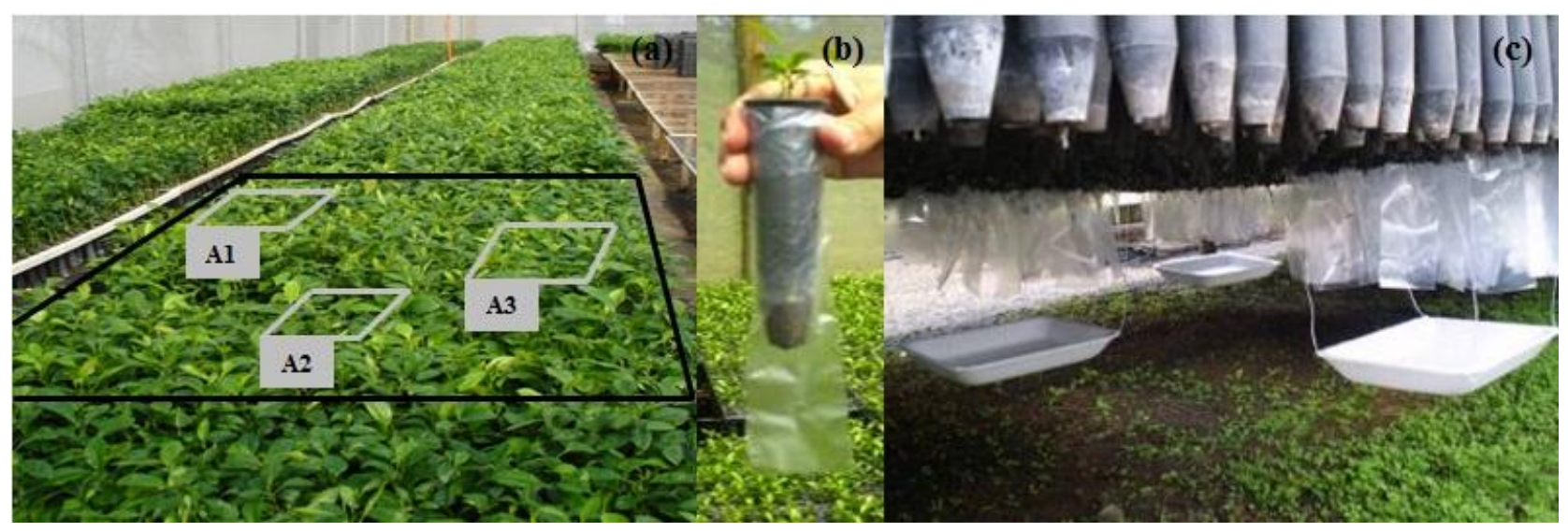

FIGURE 1. Details of the procedure for assessing the manual overhead irrigation system efficiency: (a) selection of the 3- $\mathrm{m}^{2}$ experimental plot (large rectangle) and the three $0.04-\mathrm{m}^{2} \mathrm{sub}$ sampling area (small gray rectangles); (b) $24 \times 5 \mathrm{~cm}$ plastic bags placed underneath the cone-shaped containers located in the sub-sampling area; (c) $18 \times 23 \mathrm{~cm}$ styrofoam trays underneath the sub-sampling area. The procedure was performed on benches with seedlings at the same development stage.

After the installation of the sampling structure, the experimental plot was manually irrigated. The solution application time and the system pressure were recorded. We waited 30 minutes to allow the complete leaching of the applied solution in order to collect the excess. The samples were identified and stored in an airtight box for quantification immediately after collection to avoid evaporation.

\section{Irrigation pe rformance parameters}

The irrigation performance was evaluated by determining the water or nutrient solution losses and the irrigation efficiency. The water or nutrient solution loss percentage $\left(W_{\text {loss }}\right)$ was estimated by the water collected in the plastic bags (percolation loss) and in the styrofoam trays (application loss) $\left(W d_{\text {loss }}\right)$ divided by the water applied $\left(W d_{\text {app }}\right)$ (Equation 1$)$. The water loss $\left(W d_{\text {loss }}\right)$ was determined by [eq. (2)]. The water applied $\left(W d_{a p p}\right)$ was determined in each irrigation by the relationship between the applied volume and the experimental plot area (Equation 3). The irrigation efficiency was determined by $100 \%-W d_{\text {loss }}$.

$$
\begin{aligned}
& W_{\text {loss }}=\frac{W d_{\text {loss }}}{W d_{\text {app }}} \times 100 \\
& W d_{\text {loss }}=\left(\frac{\bar{V}_{d}}{A_{\text {tray }}}+\frac{\bar{V}_{p}}{A_{\text {tube }}}\right) \\
& W d_{\text {app }}=\frac{V_{\text {app }}}{A_{\text {plot }}}
\end{aligned}
$$

where,

$$
\begin{aligned}
& W_{\text {loss }}=\text { water loss percentage }(\%) \\
& W d_{\text {loss }}=\text { average water depth loss }(\mathrm{mm}) ; \\
& W d_{\text {app }}=\text { average water depth applied }(\mathrm{mm}) ;
\end{aligned}
$$


$\bar{V}_{d}=$ average volume lost by direct runoff, obtained by the volume collected in the trays installed underneath the three sub-sampling areas $(\mathrm{L})$;

$\bar{V}_{p}=$ average volume lost by percolation, obtained by the total volume collected in the plastic bags fixed underneath the cone-shaped containers at the three sub-sampling areas (L);

$A_{\text {tray }}=$ area of a styrofoam tray fixed underneath the sampling areas $\left(\mathrm{m}^{2}\right)$;

$A_{\text {tube }}=$ upper transversal area of one cone-shaped container multiplied by the number of containers present at the sampling area $\left(\mathrm{m}^{2}\right)$;

$V_{a p p}=$ total volume applied, obtained by multiplying the system flow rate and the time of irrigation at the experimental plot (L), and

$$
A_{\text {plot }}=\text { experimental plot area }\left(\mathrm{m}^{2}\right) \text {. }
$$

To minimize the variation associated with the solution volume determination, we recommend weighing the samples using an analytical scale with one decimal place. The results should be subsequently converted into volume considering the solution density. As the sample is the sum of water and plastic bag weight, the plastic bag average weight should be subtracted from the sample. Thirty plastic bags should be weighed for obtaining the mean and standard deviation. This procedure showed a low variability in preliminary studies (data not shown).

For an estimate of total losses during the rootstock liners production, it is possible to determine the average water loss per 100 plants (Equation 4).

$$
L_{i_{100}}=\left(\frac{\overline{L_{i}}}{N p}\right) \times 100
$$

where,

$L_{i_{100}}=$ average water loss for 100 plants (L);

$\overline{L_{i}}=$ average water loss obtained by the sum of volumes lost directly and by percolation at the three sub-sampling areas (L), and

$N p=$ number of plants at the sampling area (49 plants).

The total water loss for 100 plants was obtained by multiplying $L_{i_{100}}$ (Equation 4 ) by the number of irrigations per growing stage. For this determination, is necessary to assume an average irrigation frequency, usually performed daily for GE and every other day for the other stages. This is a standard practice in irrigation performed by citrus seedling nurserymen. Thus, the total water loss of 100 plants throughout the citrus rootstock liners production cycle was estimated by summing the losses from all stages of development.

Based on the obtained data, it was possible to determine the percentage of drainage or leaching fraction (LEA-COX et al., 2001). The drainage or leaching fraction measures the excess water applied during irrigation, estimated by the ratio between the amount of water drained and the bottom cone-shaped container diameter by the amount of water applied to the container. This parameter is widely-adopted as a practical tool because represents a simple, reliable, and fast method to perform water management and control the soilless potting mix salinity since allows direct electrical conductivity measurements.

\section{Estimation of salt losses}

As most of the commercial citrus seedlings production facilities perform fertigation, our method also includes the possibility of estimating the amount of salts available in the nutrient solution. That estimative can be performed on the water collected directly and by percolation losses. 
To determine the values of the solution's electrical conductivity, we used a portable conductivity meter (model DM-32; Digimed, São Paulo, Brazil).

The samples collected to determine the volume lost directly or by percolation should be separated by each sub-sampling area, providing three readings of electrical conductivity considered three replications. The fertigation solution was also collected to determine the initial electrical conductivity and for subsequent comparison with the values obtained in the drained solution.

RHOADES et al. (1992) indicates that a solution with an electrical conductivity of $1 \mathrm{dS} \mathrm{m} \mathrm{m}^{-1}$ has approximately $700 \mathrm{mg} \mathrm{L}^{-1}$ of salts. The knowledge of the salt concentration and the volume of water lost directly and by percolation per plant by cone-shaped container allows for the determination of the total amount of salts lost per plant in each fertigation event. The multiplication of this amount by the number of fertigations in each stage of development allowed us to determine the value per stage evaluated. Summing all four stages and multiplying by the number of citrus rootstock liners produced allowed us to determine the total amount of salts loss on the nursery floor.

\section{Irrigation assessment method validation}

The proposed method was evaluated in a commercial citrus seedlings nursery registered at the São Paulo State agency. This agency regulates the citrus seedlings production industry in São Paulo (Coordenadoria de Defesa Agropecuária, Secretaria de Agricultura e Abastecimento, www.defesa.agricultura.sp.gov.br). The nursery name was kept confidential due to a mutual nondisclosure agreement. This nursery was selected for several reasons: 1) use of manual overhead irrigation system; 2) production of Rangpur lime (Citrus limonia Osbeck) 'Limeira' rootstocks, which is the primary rootstock for the Brazilian industry (PRADO et al., 2008; VALE et al., 2009); and 3) use of soilless potting mix (WRIGHT et al., 2009; GABRIEL et al., 2009; BARRETO et al., 2012). These characteristics represent the most common technologies used by citrus commercial nurseries in Brazil.

\section{Statistical analysis}

The data were submitted to analysis of variance and Tukey mean comparison test using SAS 9.2 (SAS Institute, Cary, NC, USA). Results were considered significant when $\mathrm{P} \leq 0.05$.

\section{RESULTS AND DISCUSSION}

The survey was considered easy to understand and fill out by the nurseryman. The survey contributed to the characterization of the production facility and in determining the technological profile of the commercial facility visited. The nursery presented: 1) production area of $20,000 \mathrm{~m}^{2}$, with an average annual production of 300,000 seedlings; 2) use of pine bark-based soilless potting mix; 3) use of manual overhead irrigation with breaker nozzles without any formal irrigation or fertigation management practices; 4) irrigation and fertigation applied daily at GE and every other day in ED, ID and FD; and 5) the nurseryman did not perform water and nutrient management, meaning there was no monitoring of potting mix moisture or electrical conductivity. The nursery visited presented the same irrigation system indicated by QUEIROZ et al. (2009), who made a diagnosis of salinization process in protected environments for the region of Campinas, São Paulo, Brazil.

The water depth applied and lost (directly and by percolation), the irrigation efficiency, and the drainage fraction are presented (Table 1). Plants at the GE stage received $4.68 \mathrm{~mm}$ of water depth, ED and ID $23.84 \mathrm{~mm}$ and FD $44.64 \mathrm{~mm}$ (5 to 10 times more) (P $\leq 0.05$, Table 1$)$. That difference occurred because on GE, the substrate was exposed to the air and the irrigator had to water only the surface. Liners needed more water to meet the plant water requirements. With leaf area and canopy size increasing over time due to plant growth, the leaves started redirecting more water over time ("umbrella effect"). As a result, plant growth increases the water loss by runoff and percolation over time. The water depth lost directly in GE was 13 times lower than in FD $(\mathrm{P} \leq 0.05$, Table 1). By comparing ED, ID, and FD, our results indicated that FD was $98 \%$ higher than ED 
(Table 1). The water lost by percolation was almost zero on GE, not differing among ED, ID and FD $(\mathrm{P} \leq 0.05$, Table 1). Comparing water lost by percolation to water applied on each stage of development, there was a reduction in the drainage fraction with plant growth $(60.21 \%, 53.02 \%$ and $39.87 \%$ for ED, ID and FD, respectively) ( $\mathrm{P} \leq 0.05$, Table 1$)$. Plant development determined a greater utilization of water and fertilizer solution, and the water depth applied increased due to the increase in water demand by plants $(\mathrm{P} \leq 0.05$, Table 1$)$.

The GE stage had the lowest percentage of water loss (directly and by percolation) (19.52\%), and consequently presented the greatest irrigation efficiency value $(80.48 \%)$, differing significantly from ED, ID and FD (P $\leq 0.05$, Table 1). Plants in ED, ID and FD stages of development were not different with average values of $27.14 \%$ of irrigation efficiency and $72.86 \%$ losses. Satisfactory irrigation efficiencies for systems with low and medium working pressure ranged from $65 \%$ to $75 \%$ (COELHO et al., 2005) and indicate the irrigation efficiency was not satisfactory for ED, ID and FD ( $\mathrm{P} \leq 0.05$, Table 1). Conversely, GE presented acceptable efficiency values when compared to those recommended for sprinkler irrigation (COELHO et al., 2005). However, the water depth applied at GE $(4.68 \mathrm{~mm})$ was five times lower than the other stages, resulting in only $19.52 \%$ of water loss (Table 1). Low irrigation efficiency values for ED, ID and FD demonstrate the interference by the plant canopy in the dispersion of the water depth applied, with the FD presenting the highest water depth lost directly, representing approximately $23 \%$ of the water depth applied (Table 1).

TABLE 1. Water depth applied and lost (directly, by percolation, and total), percentage of water loss, irrigation efficiency, and drainage or leaching fraction at different stages of development in the production of citrus rootstock liners in a commercial screen house. Each data point is the average of three replications. São Paulo, Brazil.

\begin{tabular}{|c|c|c|c|c|}
\hline \multirow{2}{*}{ Assessed parameters } & \multicolumn{4}{|c|}{ Rootstock liner stages of development } \\
\hline & $\mathbf{G E}^{\mathbf{r}}$ & $\mathbf{E} \bar{D}^{2^{-}}$ & $\overline{I D}^{-5}$ & $\mathbf{F D}^{4-\cdots}$ \\
\hline Water depth applied (mm) & $4.68 \pm 0 \mathrm{c}$ & $23.74 \pm 0 \mathrm{~b}$ & $23.95 \pm 0 \mathrm{~b}$ & $44.64 \pm 0 \mathrm{a}$ \\
\hline Water depth lost directly (mm) & $0.81 \pm 0.06 \mathrm{c}$ & $4.59 \pm 0.42 b$ & $5.36 \pm 1.05 \mathrm{~b}$ & $10.62 \pm 1.14 \mathrm{a}$ \\
\hline Water depth lost by percolation (mm) & $0.10 \pm 0.07 \mathrm{~b}$ & $14.30 \pm 2.69 \mathrm{a}$ & $12.70 \pm 2.33 \mathrm{a}$ & $17.80 \pm 1.91 \mathrm{a}$ \\
\hline Total water depth loss (mm) & $0.91 \pm 0.13 \mathrm{c}$ & $18.88 \pm 2.96 b$ & $18.06 \pm 1.34 \mathrm{~b}$ & $28.42 \pm 0.79 \mathrm{a}$ \\
\hline Water loss $(\%)$ & $19.52 \pm 2.72 b$ & $79.53 \pm 12.45$ & $75.41 \pm 5.60$ & $63.65 \pm 1.76 \mathrm{a}$ \\
\hline Irrigation efficiency $(\%)$ & $80.48 \pm 2.72 \mathrm{a}$ & $20.47 \pm 12.45$ & $24.59 \pm 5.60$ & $36.35 \pm 1.76 b$ \\
\hline Drainage or leaching fraction $(\%)$ & $2.17 \pm 1.42 b$ & $60.21 \pm 11.34$ & $53.02 \pm 9.73$ & $39.87 \pm 4.29 \mathrm{a}$ \\
\hline
\end{tabular}

$\overline{\text { Means followed by the same letters in rows do not differ amongst themselves }(\mathrm{P} \leq 0.05) \text { by Tukey's test. }{ }^{1} \mathrm{GE}=\mathrm{Germination} \text { and }}$ establishment ( 1 to 30 day after sowing [DAS]). ${ }^{2} \mathrm{ED}=$ Early development (31 to $\left.60 \mathrm{DAS}\right) .{ }^{3} \mathrm{ID}=$ Intermediate development $(61$ to 90 DAS). ${ }^{4} \mathrm{FD}=$ Final development (91 to 120 DAS).

The drainage or leaching fraction values are presented (Table 1). The result for GE was only $2.17 \%$ ( $\mathrm{P} \leq 0.05$, Table 1). According to ZINATI (2005), values lower than 5\% should be interpreted with care, since it may promote high concentration of soluble salts in the substrate and lead to injuries to the root system. Furthermore, values ranging between $10 \%$ and $15 \%$ are considered adequate for plant growth. It is recommended to perform irrigations with drainage or leaching fraction around $20 \%$ in order to control the salt levels over time. However, using a salinity control strategy by leaching solution for citrus seedlings production is not the most appropriate management practice since it would cause fertilizer loss and low utilization of nutrients (DIAS et 
al., 2007). As fertigation management is performed by applying fertilizer according to the crop uptake rate, it would be indicated to improve the management strategies by determining the electrical conductivity and/or partial concentration of ions in the solution (OLIVEIRA et al., 2011).

The average drainage or leaching fraction value of ED, ID and FD was 51.03\%, which was two and a half times higher than the range of $10 \%$ to $15 \%$ recommended by MORVANT et al. (2001) (Table 1). The irrigation was being performed with an additional amount of $36.03 \%$ to meet the plant demand and perform the leaching of the excessive salts; for the ED stage there was an additional application of $45.21 \%$ (Table 1 ).

The results of water loss for 100 plants are shown in Figure 2. The total water loss for the entire rootstock liner production cycle was $75 \mathrm{~L}$ or $0.075 \mathrm{~m}^{3}$. There was an increase of $88 \%$ in the volume lost from GE to ED, and of $38 \%$ from ID to FD; there were no differences between ED and ID (Figure 2). The increase in the volume lost are influenced by plant canopy and root system development, as well as by the increase in water depth applied. Considering that this commercial nursery presented an average annual production of 300,000 seedlings, the total annual loss of nutrient solution was $221.8 \mathrm{~m}^{3}$.

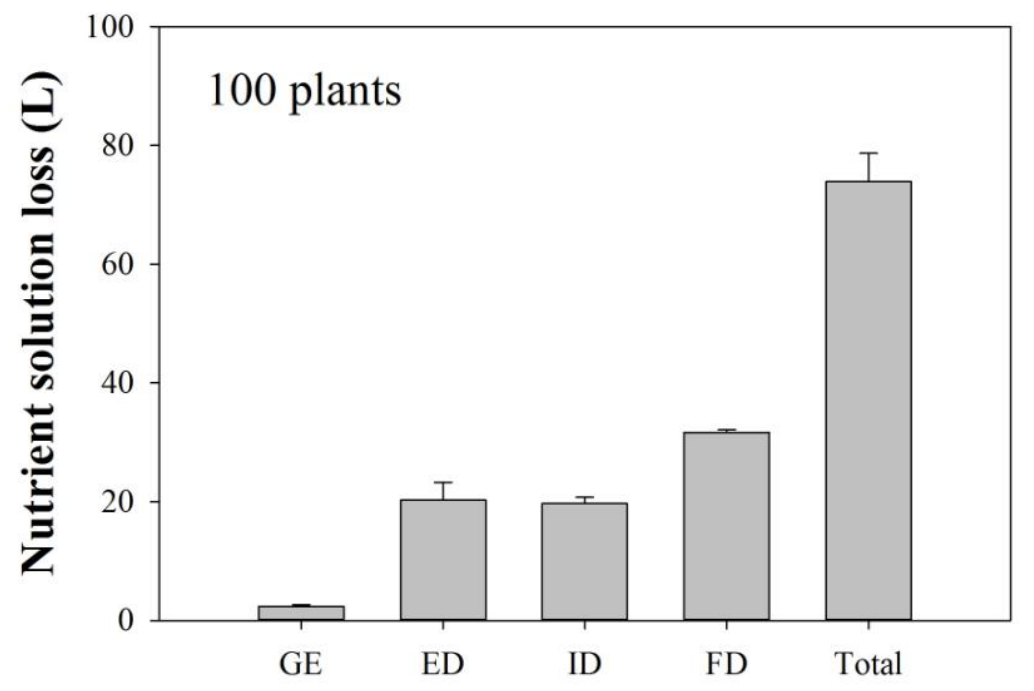

FIGURE 2. Nutrient solution loss of 100 plants at different stages of development and after 120 days (total) in the production of citrus rootstock liners in a commercial screen house. Where: $\mathrm{GE}=$ germination and establishment (1 to 30 days after sowing, DAS), ED = early development (31 to 60 DAS), ID = intermediate development (61 to 90 DAS), and $\mathrm{FD}=$ final development (91 to $120 \mathrm{DAS}$ ). Each data point is the average of three replications. São Paulo, Brazil.

The results obtained confirmed the low efficiency of the manual overhead irrigation and the need for technological innovation, focusing both in the development of new irrigation equipment such as ebb-and-flow subirrigation systems (FERRAREZI et al., 2015) and improved irrigation management practices using soil moisture sensors (FERRAREZI et al., 2013). However, it is important to note that our results underestimated the efficiency since not all the components of the mass or volume balances were included - only the most representative ones.

The electrical conductivity of the solutions applied by fertigation was $1.21 \mathrm{dS} \mathrm{m}^{-1}$. This value is below the salinity threshold of Rangpur lime $\left(1.4 \mathrm{dS} \mathrm{m}^{-1}\right.$ ) (SOUZA et al., 2012). FERNANDES et al. (2011) reported that most citrus genotypes are sensitive to salt excess and the risk of substrate salinity is high and requires constant monitoring. When the electrical conductivity is above the salinity threshold of 1.7 to $2.0 \mathrm{dS} \mathrm{m} \mathrm{m}^{-1}$ there is salt excess, which must be reduced by leaching.

Figure 3 shows the electrical conductivity values of the solution lost directly and by percolation at different stages of development. As expected, the electrical conductivity of the solution lost directly was similar to the applied solution. GE presented the highest electrical 
conductivity $\left(1.45 \mathrm{dS} \mathrm{m}^{-1}\right)$ as a result of the contact of the solution with the saline strip created on the bottom of the cone-shaped containers caused by the salt precipitation from previous fertigations (Figure 3b). The electrical conductivity of the leached solutions of GE, ID and FD showed values below those applied by the fertilizer solution (i.e., $1.21 \mathrm{dS} \mathrm{m}^{-1}$ ) (Figure 3b). However, the high leaching rate provided by the application of a drainage fraction above the recommendation can lead to nutrient leaching. Only ED presented electrical conductivity above those found in the applied solution, showing an increase in the salt concentration of the potting mix due to consecutive fertigations. This fact demonstrates the need of proper water and nutrient management, with intercalated irrigations and fertigations, avoiding the risk of salt accumulation in the substrate.

Considering an annual production of 300,000 seedlings in an area of $20,000 \mathrm{~m}^{2}$ and the average amount of salts lost (directly and by percolation) throughout the rootstock liner production stages of development, the manual overhead irrigation system releases approximately $158.9 \mathrm{~kg}$ of salts onto the nursery floor. The amount of salts deposited in the soil was significant and can cause environmental problems over time. This calculation was made assuming all water applications were made with nutrient solution with the same electrical conductivity. Therefore, taking into account that each commercial nursery has production areas with different nutritional management and that in many cases there is no appropriate technical control, this value may be an under estimation.

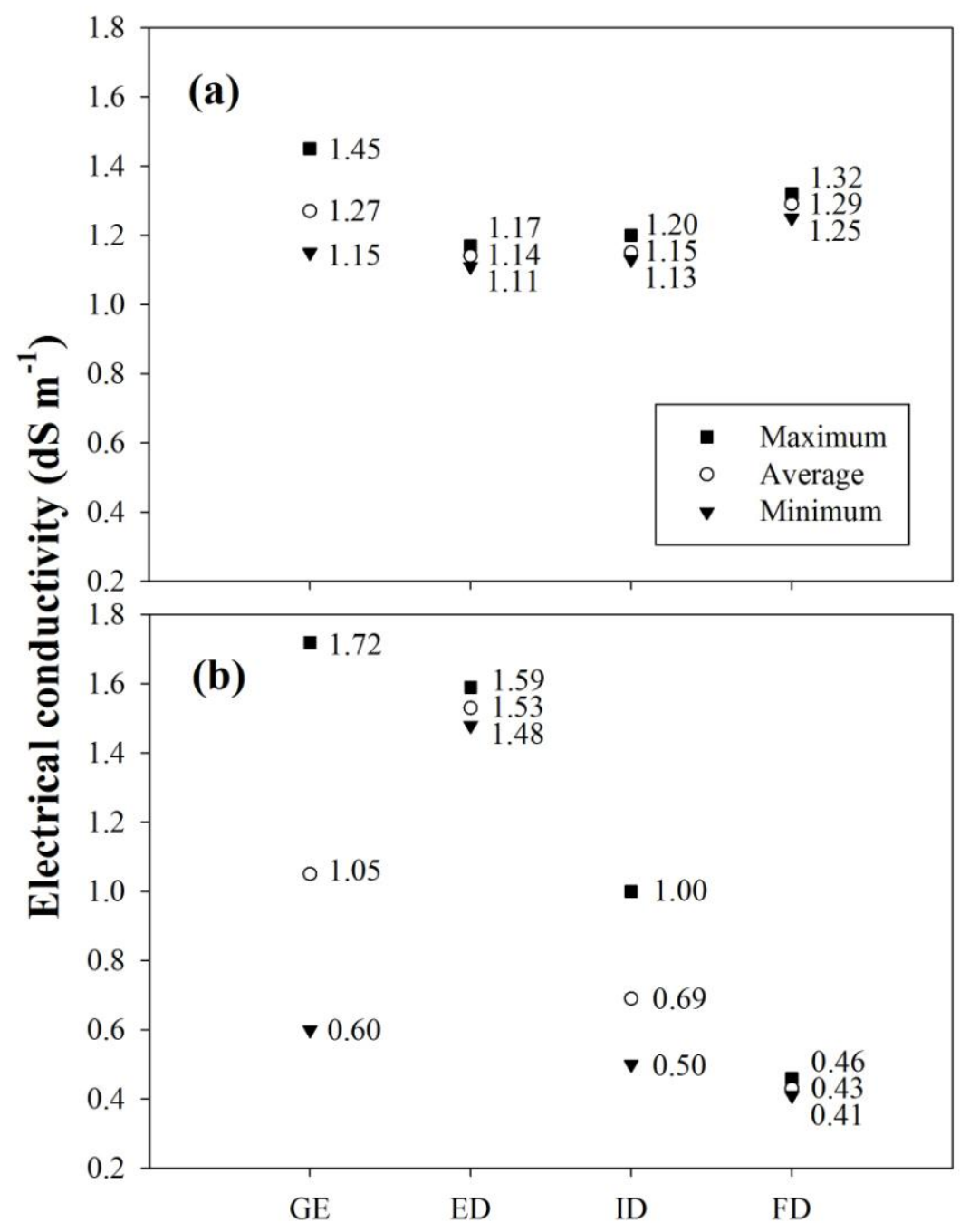

FIGURE 3. Electrical conductivity of the solution lost directly (a) and by percolation (b) at different stages of development in the production of citrus rootstock liners in a commercial screen house. Where: GE = germination and establishment (1 to 30 days after sowing, $\mathrm{DAS}$ ), $\mathrm{ED}=$ early development (31 to $60 \mathrm{DAS}), \mathrm{ID}=$ intermediate development (61 to 90 DAS), and FD = final development (91 to 120 DAS). Each data point is the average of three replications. São Paulo, Brazil. 
Due to easiness for finding the needed materials and supplies, the simplicity of operational procedures, fast equipment assembly, low cost, and accurate and repeatable results, this method proved to be simple and feasible to be applied in the citrus rootstock liners production system. In addition, the materials used to collect the samples met the legal requirements related to phytosanitary issues of production, i.e., they were made of plastic material, without previous use, and disposed after sampling. However, there was a difficulty in allocating the experimental plots due to the rootstock heterogeneity at the same development stage, which is due to the nonuniformity of nutrient solution application.

\section{CONCLUSIONS}

The proposed method proved to be simple, fast, accurate, and reliable in assessing the efficiency of manual overhead irrigation. The results generated by the utilization of the method showed that irrigation at the commercial screen house has been performed without effective control of the water depth, generating low irrigation efficiency, and high volumes of water loss, using a drainage and leaching fraction above the recommendation for citrus. More efficient irrigation systems are necessary for sustainable citrus rootstock liners production.

\section{ACKNOWLEDGEMENTS}

We thank Citrograf Mudas, the commercial nursery where the assessment method was tested, the School of Agricultural Engineering/University of Campinas and the Irrigation and Environment Technology Research Group for technical support. Funding for this research was provided by the National Council of Technological and Scientific Development (CNPq) (awards 479,394/2006-7 and 479,665/2009-5) and CAPES (Ministry of Education, Brazil).

\section{REFERENCES}

BARRETO, C.V.G; TESTEZLAF, R.; SALVADOR, C.A. Dinâmica do potencial matricial em substratos de pinus e coco sob ação da capilaridade. Horticultura B rasileira, Brasília, v.30, n.1, p.26-31, 2012.

BATAGLIA, O.C.; FURLANI, P.R.; FERRAREZI, R.S.; MEDINA, C.L. Nutritional guidelines for citrus seedlings production. Araraquara: Vivecitrus, 2008, 40p. (Technical Bulletin).

BUMGARNER, M.L.; SALIFU, K.F.; JACOBS, D.K. Subirrigation of Quecus rubra seedlings: nursery stock quality, media chemistry, and early field performance. HortScience, Alexandria, v.47, n.7, p.2179-2185, 2008.

CARVALHO, S.A.; GRAF, C.C.D.; VIOLANTE, A.R. Produção de material básico e propagação. In: MATTOS JÚNIOR, D.; DE NEGRI, J.D.; PIO, R.M.; POMPEU JÚNIOR, J. (Ed.). Citros. Campinas: Instituto Agronômico/IAC e FUNDAG, 929p., 2005.

COELHO, E.F.; COELHO, M.A.; OLIVEIRA, S.L. Agricultura irrigada: eficiência de irrigação e de uso de água. Bahia Agrícola, Salvador, v.7, n.1, p.57-60, 2005.

DIAS, N.S.; DUARTE, S.N; TELES FILHO, J.F.; YOSHINAGA, R.T. Salinização do solo por aplicação de fertilizantes em ambiente protegido. Irriga, Botucatu, v.12, n.1, p.135-143, 2007.

FERNANDES, P.D.; BRITO, M.E.B.; GHEYI, H.R.; SOARES FILHO, W.S.; MELO, A.S.; CARNEIRO, P.T. Crescimento de híbridos e variedades porta-enxerto de citros sob salinidade. Acta Scientia rum. Agronomy, Maringá, v.33, n.2, p.259-267, 2011.

FERRAREZI, R.S.; RIBEIRO, M.D.; VAN IERSEL, M.W.; TESTEZLAF, R. 2013. Subirrigation controlled by capacitance sensors for citrus rootstock production. HortScience, Alexandria, v.48, n.9, S142 (Abstr.). 
FERRAREZI, R.S.; SANTOS, L.N.S.; SOUS A, A.C.M.; PEREIRA, F.F.S.; ELAIUY, M.L.C; TORREL, U.; MATSURA, E.E. Altura de lâmina, tempo e volume de enchimento de um equipamento de irrigação por pavio e determinação da uniformidade de distribuição de água em substratos. B ragantia, Campinas, v.71, n.2, p.1-9, 2012.

FERRAREZI, R.S.; WEAVER, G.M.; VAN IERSEL, M.W.; TESTEZLAF, R. Subirrigation: Historical overview, challenges, and future prospects. HortTechnology, Alexandria, v.25, n.3, p. 262-276, 2015.

GABRIEL, M.Z.; ALTLAND, J.E.; OWEN JUNIOR, J.S. The effect of physical and hydraulic properties of peat moss and pumice on Douglas Fir Bark based soilless substrates. HortScience, Alexandria, v.44, n.3, p.874-878, 2009.

GIRARDI, E.A.; MOURÃO FILHO, F.A.A.; ALVES, A.S.R. Mudas de laranja Valência sobre dois porta-enxertos e sob diferentes manejos de adubação. Revista Brasileira de Fruticultura, Jaboticabal, v.32, n.3, p.855-864, 2010.

JUSTI, A.L.; VILAS BO AS, M.A.; SAMPAIO, S.C. Índ ice de capacidade do processo na avaliação da irrigação por aspersão. Engenharia Agrícola, Jaboticabal, v.30, n.2, p.264-270, 2010.

LEA-COX, J.D.; ROSS, D.S.; TEFFEAU, K.M. A water and nutrient management planning process for container nursery and greenhouse production systems in Maryland. Journal of Environmental Horticulture, Washington, v.19, n.4, p.230-236, 2001.

MORVANT, J.K.; DOLE, J.M.; COLE, J.C.; Fertilizer source and irrigation system affect geranium growth and nitrogen retention. HortScience, Alexandria, v.36, n.6, p.1022-1026, 2001.

OLIVEIRA, F.A.; MEDEIROS, J.F.; DUARTE, S.N.; SILVA JÚNIOR, M.J.; CAMPELO, C.M. Calibração de extratores providos de cápsula porosa para monitoramento da salinidade e da concentração de íons. Engenharia Agrícola, Jaboticabal, v.31, n.3, p.520-528, 2011.

PRADO, R.M; ROZANE, D.E.; CAMAROTTI, G.S.; CORREIA, M.A.R.; NATALE, W.; BARBOSA, J.C.; BEUTLER, A.N. Nitrogênio, fósforo e potássio na nutrição e na produção de mudas de laranjeiras Valência, enxertada sobre citrumeleiro Swingle. Revista Brasileira de Fruticultura, Jaboticabal, v.30, n.3, p.812-817, 2008.

QUEIROZ, S.O.P.; TESTEZLAF, R.; MATSURA, E.E. Metodologia para avaliação da salinidade do solo em ambiente protegido. Irriga, Botucatu, v.14, n.3, p.383-397, 2009.

RHOADES, J.; KANDIAH, A.; MASHALI, A.M. The use of saline water for crop production. Rome: FAO, 1992, 133p. (Irrigation and Drainage Paper, 48).

RIBEIRO, M.D.; FERRAREZI, R.S.; TESTEZLAF, R. Assessment of subirrigation performance in eucalyptus seedling production. HortTechnology, Alexandria, v.24, n.2, p.231-237, 2014.

ROZANE, D.E.; PRADO, R.M.; NATALE, W.; BEUTLER, A.N.; SILVA, S.R.; BARBOSA, J.C. Efeitos das doses de nitrogênio, fósforo e potássio na nutrição e na produção do porta-enxerto de limoeiro cravo. Acta Scientiarum. Agronomy, Maringá, v.31, n.2, p.255-260, 2009.

SALVADOR, C. A. Sistema de irrigação por capilaridade na produção de porta-enxerto de mudas cítricas na fase de sementeira. 123p. Dissertação (Mestrado em Engenharia Agrícola) Faculdade de Engenharia Agrícola, Universidade Estadual de Campinas, Campinas, 2010.

SOUZA, J.W.; BOTREL, T.A.; CARVALHO, D.F.; SILVA, L.D.B. Fertigação em mudas de citros utilizando-se mangueiras e microtubos sob regime de escoamento turbulento. Revista Brasileira de Engenharia Agrícola e Ambiental, Campina Grande, v.15, n.8, p.816-822, 2011a.

SOUZA, A.L.; MATSURA, E.E.; MIRANDA, J.H.; COLOMBO, A. Ajuste de parâmetros de transporte de solutos no solo utilizando matlab 6.5. Engenharia Agrícola, Jaboticabal, v.31, n.6, p.1064-1074, 2011b. 
SOUZA, T.R.; VILLAS BÔAS, R.L.; QUAGGIO, J.A.; SALOMÃO, L.C.; FORATTO, L.C. Dinâmica de nutrientes na solução do solo em pomar fertirrigado de citros. Pesquisa Agropecuária Brasileira, Brasília, v.47, p.846-854, 2012.

TEIXEIRA, P.T.L.; SHÄFER, G.; SOUZA, P.V.D.; TODESCHINI, A. Desenvolvimento vegetativo de porta-enxertos cítricos produzidos em diferentes recipientes. Ciência Rural, Santa Maria, v.39, n.6, p.1695-1700, 2009a.

TEIXEIRA, P.T.L.; SHÄFER, G.; SOUZA, P.V.D.; TODESCHINI, A. A escarificação química e o desenvolvimento inicial de porta-enxerto cítricos. Revista Brasileira de Fruticultura, Jaboticabal, v.31, n.3, p.865-871, 2009b.

TEIXEIRA, P.T.L.; SHÄFER, G.; SOUZA, P.V.D.; TODESCHINI, A. Desenvolvimento vegetativo e acúmulo de massa seca com a adubação de porta-enxertos cítricos cultivados em tubetes. Ciência Rural, Santa Maria, v.40, n.12, p.2603-2607, 2010.

VALE, D.W.; PRADO, R.M.; SOUZA, H.A.; MARTINS, A.B.G. Doses de nitrogênio, fósforo e potássio na nutrição de porta enxerto cítrico de limoeiro 'cravo'. Scientia Agraria, Curitiba, v.10, n.1, p.61-66, 2009.

WRIGHT, R.D.; JACKSON, B.E.; BARNES, M.C.; BROWDER, J.F. The landscape performance of annual bedding plants grown in pine tree substrate. HortTechnology, Alexandria, v.19, n.1, p.78-82, 2009.

ZINATI, G.M. Irrigation management options for containerized grown nursery crops. New Jersey Agricultural Experiment Extension. Rutgers Cooperative Research \& Extension. New Jersey: 2005. (Bulletin E 302). 